\title{
Aberrant promoter methylation of hOGG1 may be associated with increased risk of non-small cell lung cancer
}

\author{
Hualong Qin ${ }^{1, *}$, Jianjie Zhu ${ }^{2,3, *}$, Yuanyuan Zeng ${ }^{2,3, *}$, Wenwen $\mathrm{Du}^{2}$, Dan Shen ${ }^{2}$, Zhe \\ Lei $^{4}$, Qian Qian ${ }^{5}$, Jian-an Huang ${ }^{2,3}$, Zeyi Liu' ${ }^{2,3}$ \\ ${ }^{1}$ Department of Cardiothoracic Surgery, The First Affiliated Hospital of Soochow University, Suzhou, 215006, China \\ ${ }^{2}$ Department of Respiratory Medicine, The First Affiliated Hospital of Soochow University, Suzhou, 215006, China \\ ${ }^{3}$ Institute of Respiratory Diseases, Soochow University, Suzhou, 215006, China \\ ${ }^{4}$ Laboratory of Cancer Molecular Genetics, Medical College of Soochow University, Suzhou 215123, China \\ ${ }^{5}$ Division of Allergy \& Immunology, Department of Medicine, National Jewish Health, Denver, CO 80206, USA \\ *These authors have contributed equally to this work \\ Correspondence to: Zeyi Liu, email: liuzeyisuda@163.com \\ Jian-an Huang, email: huang_jian_an@yeah.net
}

Keywords: non-small cell lung cancer, base excision repair, hOGG I, SNP, methylation

Received: August 31, 2016

Accepted: November 22, 2016

Published: December 26, 2016

\section{ABSTRACT}

DNA methylation may epigenetically inactivate tumor suppressor genes in NSCLC. As the human 8-oxoguanine DNA glycosylase (hOGG1) gene promoter is frequently methylated in NSCLC, we evaluated whether genetic or epigenetic alterations of hOGG1 are associated with increased risk of non-small cell lung cancer. Three hOGG1 haplotype-tagging SNPs (htSNP) were genotyped in PCR-restriction fragment length polymorphism assays, and one htSNP was genotyped in a PCR-single-strand conformation polymorphism assay in case-control studies of 217 NSCLC patients and 226 healthy controls. The methylation profiles of peripheral blood mononuclear cell specimens from 121 NSCLC patients and 121 controls were determined through methylation-specific PCR of hOGG1. No differences in allele or genotype frequencies between NSCLC patients and controls were observed at any of the four polymorphic sites (rs159153, rs125701, rs1052133, and rs293795). However, hOGG1 methylationpositive carriers had a $\mathbf{2 . 2 5}$-fold greater risk of developing NSCLC (adjusted odds ratio: 2.247 ; $95 \%$ confidence interval: $1.067-4.734 ; P=0.03$ ) than methylationfree subjects. Furthermore, the demethylating agent 5-aza-2'-deoxycytidine restored hOGG1 expression in NSCLC cell lines. These data provide strong evidence of an association between peripheral blood mononuclear cell hOGG1 methylation and the risk of NSCLC in a Chinese population.

\section{INTRODUCTION}

Lung cancer is the leading cause of cancer-related death in China and worldwide [1,2]. Non-small cell lung cancer (NSCLC) accounts for approximately $85 \%$ of lung cancer cases. Despite improvements in cancer treatment, the five-year survival rate for patients with this cancer is still less than $10 \%$. However, if patients are diagnosed with cancer and receive surgery at an early stage, the fiveyear survival rate can be as high as $55-80 \%$ [3]. It has been suggested that NSCLC could result from the accumulation of multiple genetic or epigenetic changes, including DNA methylation, histone acetylation [4], and dysregulation of microRNA [5, 6]. Increased understanding of the mechanisms of tumor development and progression will be important for early detection, prevention, and targeted treatment for NSCLC.

There is frequently functional overlap in DNA repair pathways, guaranteeing genomic stability and challenging the concept that various lesions in the mammalian genome are repaired by different mechanisms. This is particularly true for oxidatively damaged DNA (e.g., oxidized bases) [7], which may result from ionizing radiation or oxidant exposure, as well as from normal cellular metabolism. Oxidized bases are cytotoxic and mutagenic, and several lines 
of evidence indicate that they may contribute to aging, neurodegeneration, and cancer [8]. Base excision repair (BER) is an important DNA repair pathway for base damage and single-strand breaks caused by X-rays, oxygen radicals, or alkylating agents [9].

One of the enzymes in the DNA BER pathway is 8-oxoguanine DNA glycosylase (OGG1). This DNA repair glycosylase is localized to both the nucleus and mitochondria, and is the main enzyme that identifies and excises 8-oxoG lesions that produce $\mathrm{G}: \mathrm{C}$ to $\mathrm{T}: \mathrm{A}$ transversions [10-12]. The human OGG1 gene ( $h O G G 1$ ) is found on chromosome $3 \mathrm{p} 26.2$, which is one of the most frequent regions of genomic deletion and contains potential tumor suppressor genes for various types of tumors (e.g., NSCLC) [13]. hOGG1 is a polygenetic gene that plays a role in several disease pathways, including various cancers [14-16]. Genetic variants in $h O G G 1$, including single-nucleotide polymorphisms (SNPs), may affect the expression and function of the OGG1 protein, thus contributing to the risk of NSCLC and influencing the prognosis of patients. Ser326Cys is the most highly investigated $h O G G 1 \mathrm{SNP}$, and several studies have suggested that the Cys326 allele is associated with increased risk of lung cancer [17-19]. However, the function of Ser326 remains controversial [20-23].

It is well established that gene expression can be epigenetically regulated via changes in DNA methylation [24-26], which frequently occur in $\mathrm{CpG}$ islands around the 5'-untranslated regions (5'-UTRs) of genes [27]. In particular, site-specific DNA methylation alterations in $\mathrm{CpG}$ islands, including the hypomethylation of oncogenes and the hypermethylation of tumor suppressor genes, may be crucial promoters of cancer progression [24, 28]. Our previous studies support the notion that DNA methylation could epigenetically inactivate tumor suppressor genes on the short arm of chromosome 3p in NSCLC [13] and thus increase the risk of non-small cell lung cancer [29]. Hence, we hypothesized that hypermethylation of the hOGGl promoter in peripheral blood mononuclear cells (PBMCs) could affect $h O G G 1$ mRNA expression and increase the risk of NSCLC.

To verify the relationship between the genetic variants and susceptibility to NSCLC comprehensively, we first genotyped four $h O G G 1$ SNPs (htSNP) using PCR-restriction fragment length polymorphism analysis, and one htSNP using PCR-single-strand conformation polymorphism analysis. The four htSNPs, including two in the $5^{\prime}$ flanking region, one in an intronic region, and one in the $3^{\prime}$ flanking region of the $h O G G 1$ gene, appropriately captured all of the common haplotype blocks reconstructed in HapMap Phase II data. In addition, the methylation status of the promoter region was detected by methylation-specific PCR (MSP) in Chinese population-based case-control studies.

\section{RESULTS}

\section{Characteristics of patients with lung cancer and controls}

The general clinical characteristics of 217 NSCLC patients and 226 cancer-free controls are listed in Table 1. The NSCLC patients and cancer-free controls were comparable with regard to the distribution of gender and age (all $P>0.05$ ).

\section{hOGG1 genotypes and the risk of lung cancer}

To determine whether any of the four promoter variants in hOGG1 (rs159153, rs125701, rs1052133, and rs293795) modify the risk of lung cancer, we genotyped participants for these four SNPs. The genotype frequencies of these polymorphisms were in Hardy-Weinberg equilibrium in the controls. To further validate these results, we used a sequencing method to genotype these SNPs; representative genotyping results are presented in Figure 1. No significant differences were observed in the allele and genotype frequencies of any of these four polymorphic sites between NSCLC patients and controls (Table 2). After stratifying subjects by age, gender, smoking history and histology, we did not observe any association of these polymorphisms with lung cancer risk in either group (Table 3).

\section{hOGG1 haplotypes and risk of lung cancer}

Association studies based on haplotypes of multiple markers have significantly greater power than genotypes at single markers for mapping and characterizing diseasecausing genes [30]. Thus, we sought to assess whether various haplotypes consisting of the four SNPs of the hOGG1 promoter (rs159153, rs125701, rs1052133, rs293795) were associated with the risk of lung cancer. As shown in Figure 2, linkage disequilibrium (LD) analysis revealed that the $\mathrm{D}^{\prime}$ values of rs 159153 with rs 125701 and of rs 159153 with rs 293795 were $>0.80$. In contrast, the $\mathrm{D}^{\prime}$ values of rs 159153 with rs 125701 and of rs 159153 with rs 293795 were $<0.80$ in the controls $\left(\mathrm{D}^{\prime}=1.0\right.$ vs. $\mathrm{D}^{\prime}=0.5$, $\mathrm{D}^{\prime}=0.99$ vs. $\mathrm{D}^{\prime}=0.66$ ). Accordingly, four-SNP haplotypes (rs159153, rs125701, rs1052133, and rs293795) and two-SNP haplotypes (rs159153, rs125701, and rs159153, rs293795) were reconstructed according to the genotyping data from the NSCLC patients and controls. Using haplotypes with frequencies of $>0.02$ for further analysis, we found that no haplotype was associated with significantly greater risk of lung cancer (Tables 4 and 5).

\section{The frequency of $h O G G 1$ promoter methylation and NSCLC risk}

Our previous work indicated that DNA methylation could epigenetically inactivate tumor suppressor genes in NSCLC. Moreover, the hOGGl gene promoter is 
Table 1: Characteristics of the case-control study subjects

\begin{tabular}{|c|c|c|}
\hline \multirow[t]{2}{*}{ Variable } & NSCLC Patients & Controls \\
\hline & $\mathrm{N}=217, \mathrm{n}(\%)$ & $\mathrm{N}=226, \mathrm{n}(\%)$ \\
\hline \multicolumn{3}{|l|}{ Age (yrs) } \\
\hline$<50$ & $23(10.6)$ & $73(32.3)$ \\
\hline $50-69$ & $145(66.8)$ & $104(46.0)$ \\
\hline$\geq 70$ & $49(22.6)$ & $49(21.7)$ \\
\hline Mean \pm SD & $62.10 \pm 9.76$ & $55.26 \pm 16.06$ \\
\hline \multicolumn{3}{|l|}{ Sex } \\
\hline Male & $154(71.0)$ & $134(59.2)$ \\
\hline Female & $63(29.0)$ & $92(40.8)$ \\
\hline \multicolumn{3}{|l|}{ TNM stage } \\
\hline I & $58(26.7)$ & \\
\hline II & $46(21.2)$ & \\
\hline III & $39(17.9)$ & \\
\hline IV & $74(34.1)$ & \\
\hline \multicolumn{3}{|l|}{ Histological type } \\
\hline Adenocarcinoma & $78(35.9)$ & \\
\hline Squamous carcinoma & 99 (45.6) & \\
\hline Others & $40(18.5)$ & \\
\hline
\end{tabular}

frequently methylated in NSCLC $[13,29]$. Therefore, we used methylation-specific PCR (MSP) to determine the methylation profiles for $h O G G 1$ in PBMC specimens from 121 NSCLC patients and 121 controls. Representative bands from MSP analysis are shown in Figure 3A. Among NSCLC patients, the frequency of hOGGl promoter methylation was $19.83 \%$. In contrast, a lower frequency of $h O G G 1$ methylation $(9.92 \%)$ was detected in controls (Table 6). To determine whether positivity for hOGGl methylation increases the risk of NSCLC, we performed logistic regression analysis to assess the odds ratios (ORs) for NSCLC in the paired cohort. The risk of NSCLC was significantly greater among those with methylation of $h O G G 1$ than among those who were methylation-free (2.25-fold, $P<0.05$, Table 6).

\section{Differential expression of $h O G G 1$ mRNA is associated with DNA methylation in NSCLC cell lines}

To determine whether methylation of the hOGG1 gene promoter is an alternative mechanism of inactivating hOGG1 mRNA expression, we evaluated mRNA expression after treating NSCLC cell lines with the demethylating agent 5-aza-2'-deoxycytidine (5-Aza) (Figure 3B). hOGG1 mRNA expression was elevated in 5-aza-treated NSCLC cell lines (A549, H460, SPC-A1, 95D, and SK-MES-1), suggesting that hOGG1 mRNA expression is associated with DNA methylation.

\section{DISCUSSION}

Epidemiological evidence has documented that lung cancer incidence and mortality have increased markedly over the past decade in China [2]. One promising treatment approach for lung cancer is the identification of lung cancer-specific biomarkers at an early stage. NSCLC could result from the accumulation of multiple genetic and/or epigenetic aberrations, and DNA methylation could epigenetically inactivate tumor suppressor genes in NSCLC [13]. The de novo methylation of $\mathrm{CpG}$ islands within the promoters of tumor suppressor genes is one of the most frequently acquired epigenetic changes during the pathogenesis of lung cancer, and is usually associated with the transcriptional downregulation of the affected genes. The analysis of DNA methylation patterns in the sputum, bronchial fluid, plasma, or serum could become a powerful tool for the accurate and early diagnosis of lung cancer, with unparalleled specificity and sensitivity $[29,31,32]$. 
Genetic variants of $h O G G 1$, including SNPs, may affect the expression and function of the OGG1 protein, thus contributing to the risk of NSCLC and influencing the prognosis of patients $[33,34]$. In an effort to validate the association of $h O G G 1$ SNPs or haplotypes with NSCLC risk, we analyzed tagging SNPs and

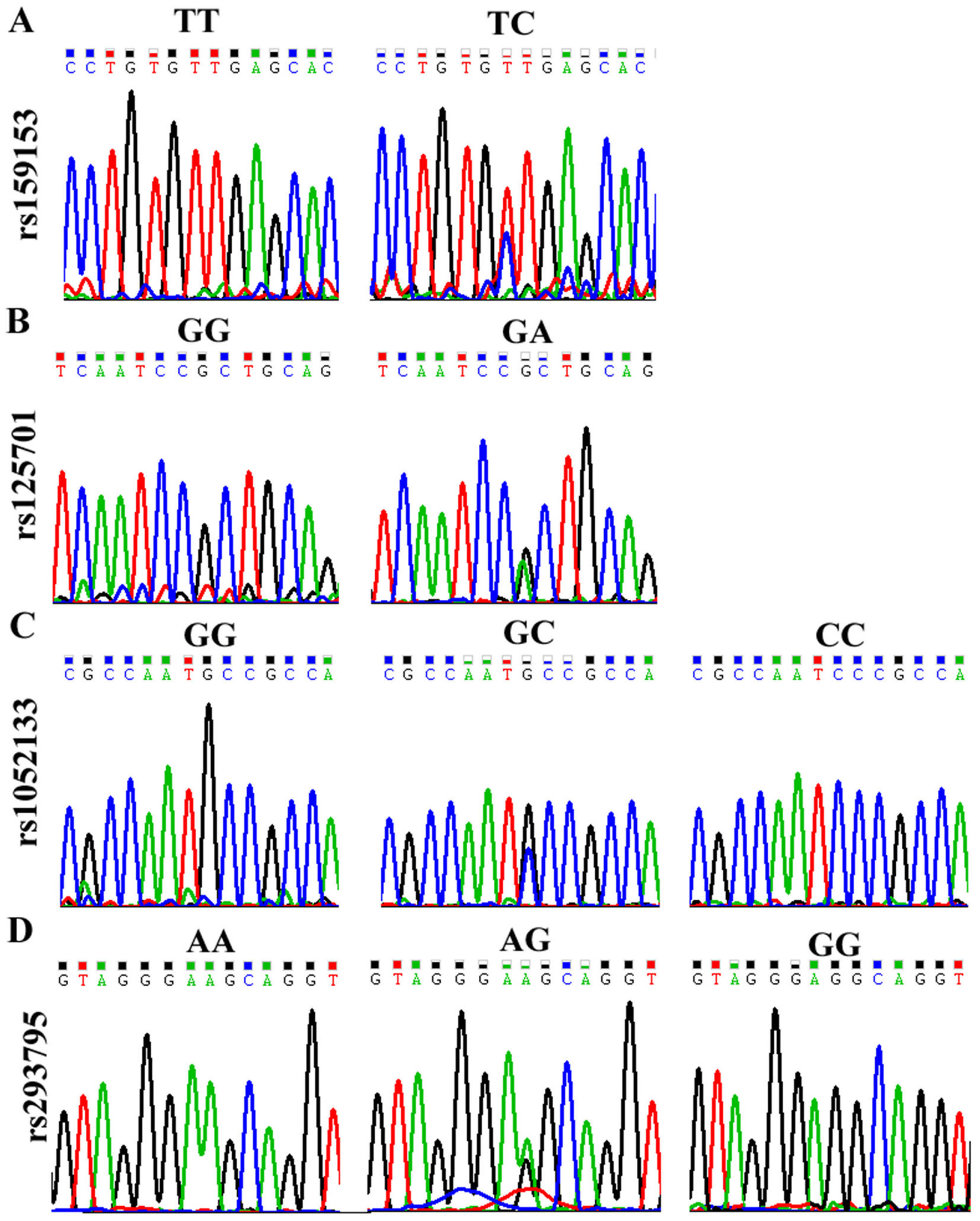

Figure 1: DNA sequencing results of a typical genotyping experiment. A. rs159153, B. rs125701, C. rs159153, and D. rs293795. 
Table 2: Genotype and allele frequencies of haplotype tagging SNPs among NSCLC cases and controls, and associations with the risk of NSCLC

\begin{tabular}{|c|c|c|c|c|c|c|c|}
\hline \multirow{3}{*}{ rs159153 } & & \multirow{2}{*}{$\begin{array}{c}\text { Cases } \\
\mathrm{N}=\mathbf{2 1 7}, \mathrm{n}(\%)\end{array}$} & \multirow{2}{*}{$\begin{array}{c}\text { Controls } \\
\mathrm{N}=226, \mathrm{n}(\%)\end{array}$} & \multirow[t]{2}{*}{$p$} & \multirow{2}{*}{$\begin{array}{l}p \text { for } \\
\text { HWE }\end{array}$} & \multirow[t]{2}{*}{ OR(95\%CI) } & \multirow[t]{2}{*}{$p$} \\
\hline & & & & & & & \\
\hline & & & & & & & \\
\hline & $\mathrm{TT}$ & $187(86.2)$ & $197(87.2)$ & 0.758 & 0.588 & 1.00 & \\
\hline & $\mathrm{TC}$ & $30(13.8)$ & $29(12.8)$ & & & $1.090(0.630-1.886)$ & 0.758 \\
\hline & $\mathrm{CC}$ & $0(0.0)$ & $0(0.0)$ & & & & \\
\hline & $\mathrm{TC} / \mathrm{CC}$ & $30(13.8)$ & $29(12.8)$ & & & $1.090(0.630-1.886)$ & 0.758 \\
\hline \multirow[t]{2}{*}{ Allele } & $\mathrm{T}$ & 404(93.1) & $423(93.6)$ & & & 1.00 & \\
\hline & $\mathrm{C}$ & $30(6.9)$ & $29(6.4)$ & & & $1.083(0.639-1.837)$ & 0.767 \\
\hline \multicolumn{8}{|l|}{ rs 125701} \\
\hline \multirow[t]{4}{*}{ Genotype } & GG & $200(92.2)$ & $203(89.8)$ & 0.390 & 0.723 & 1.00 & \\
\hline & GA & $17(7.8)$ & $23(10.2)$ & & & $1.333(0.691-2.570)$ & 0.390 \\
\hline & AA & $0(0.0)$ & $0(0.0)$ & & & & \\
\hline & GA/AA & $17(7.8)$ & $23(10.2)$ & & & $1.333(0.691-2.570)$ & 0.390 \\
\hline \multirow[t]{2}{*}{ Allele } & G & $417(96.1)$ & $429(94.9)$ & & & 1.00 & \\
\hline & A & $17(3.9)$ & $23(5.1)$ & & & $1.315(0.693-2.497)$ & 0.401 \\
\hline \multicolumn{8}{|l|}{ rs 1052133} \\
\hline \multirow[t]{4}{*}{ Genotype } & GG & $59(27.2)$ & $72(31.9)$ & 0.391 & 0.121 & 1.00 & \\
\hline & GC & $121(55.8)$ & $124(54.9)$ & & & $1.191(0.778-1.823)$ & 0.421 \\
\hline & $\mathrm{CC}$ & $37(17.0)$ & $30(13.2)$ & & & $1.505(0.833-2.720)$ & 0.175 \\
\hline & $\mathrm{GC} / \mathrm{CC}$ & $158(72.8)$ & $154(68.1)$ & & & $1.252(0.831-1.886)$ & 0.282 \\
\hline \multirow[t]{2}{*}{ Allele } & G & $239(55.1)$ & $268(59.3)$ & & & 1.00 & \\
\hline & $\mathrm{C}$ & $195(44.9)$ & $184(40.7)$ & & & $1.188(0.910-1.551)$ & 0.204 \\
\hline \multicolumn{8}{|l|}{ rs293795 } \\
\hline \multirow[t]{4}{*}{ Genotype } & $\mathrm{TT}$ & 199(91.7) & $210(92.9)$ & 0.378 & 0.458 & 1.00 & \\
\hline & $\mathrm{TC}$ & $14(6.5)$ & $15(5.8)$ & & & $0.985(0.464-2.093)$ & 0.968 \\
\hline & $\mathrm{CC}$ & $4(1.8)$ & $1(1.3)$ & & & $4.221(0.468-38.091)$ & 0.163 \\
\hline & $\mathrm{TT} / \mathrm{CC}$ & $18(8.3)$ & $16(7.1)$ & & & $1.187(0.589-2.393)$ & 0.631 \\
\hline \multirow[t]{2}{*}{ Allele } & $\mathrm{T}$ & 412(94.9) & $433(95.8)$ & & & 1.00 & \\
\hline & $\mathrm{C}$ & $22(5.1)$ & $19(4.2)$ & & & $1.217(0.649-2.281)$ & 0.540 \\
\hline
\end{tabular}

$p$ value for Chi-square analysis or Fisher's exact test. HWE, Hardy-Weinberg equilibrium

haplotypes to capture the genetic variants of $h O G G 1$ in the Chinese population comprehensively. There were no significant differences in allele and genotype frequencies or even haplotypes between NSCLC patients and controls. This suggests that no individual $h O G G 1 \mathrm{SNP}$ examined in this study is associated with NSCLC risk.
Given the above observations, additional studies were needed to determine whether aberrant promoter methylation of $h O G G 1$ increases the risk of developing NSCLC. First, to determine whether methylation of the hOGG1 gene promoter is an alternative mechanism of inactivating $h O G G 1 \mathrm{mRNA}$ expression, we evaluated hOGG1 mRNA expression after treating NSCLC cell 
Table 3: Associations between genotypes and clinical characteristics of NSCLC

\begin{tabular}{|c|c|c|c|c|}
\hline & \multicolumn{3}{|c|}{ Genotypes } & \multirow[t]{2}{*}{$p$} \\
\hline & wt/wt & $\mathbf{w t} / \mathbf{m t}$ & $\mathbf{m t} / \mathbf{m t}$ & \\
\hline \multicolumn{5}{|l|}{ rs159153 } \\
\hline \multicolumn{5}{|l|}{ Histology } \\
\hline Adenocarcinoma & 69 & 8 & 1 & \\
\hline Squamous carcinoma & 80 & 18 & 1 & \\
\hline Others & 38 & 2 & 0 & 0.221 \\
\hline \multicolumn{5}{|l|}{ TNM Stage } \\
\hline $\mathrm{I}+\mathrm{II}$ & 92 & 11 & 1 & \\
\hline III+IV & 95 & 17 & 1 & 0.618 \\
\hline \multicolumn{5}{|l|}{ rs125701 } \\
\hline \multicolumn{5}{|l|}{ Histology } \\
\hline Adenocarcinoma & 69 & 9 & 0 & \\
\hline Squamous carcinoma & 93 & 6 & 0 & \\
\hline Others & 37 & 3 & 0 & 0.414 \\
\hline \multicolumn{5}{|l|}{ TNM Stage } \\
\hline $\mathrm{I}+\mathrm{II}$ & 99 & 5 & 0 & \\
\hline $\mathrm{III}+\mathrm{IV}$ & 101 & 12 & 0 & 0.111 \\
\hline \multicolumn{5}{|l|}{ rs1052133 } \\
\hline \multicolumn{5}{|l|}{ Histology } \\
\hline Adenocarcinoma & 23 & 47 & 15 & \\
\hline Squamous carcinoma & 23 & 54 & 15 & \\
\hline Others & 13 & 20 & 7 & 0.908 \\
\hline \multicolumn{5}{|l|}{ TNM Stage } \\
\hline I+II & 36 & 53 & 15 & \\
\hline $\mathrm{III}+\mathrm{IV}$ & 23 & 68 & 22 & 0.058 \\
\hline \multicolumn{5}{|l|}{ rs293795 } \\
\hline \multicolumn{5}{|l|}{ Histology } \\
\hline Adenocarcinoma & 68 & 8 & 2 & \\
\hline Squamous carcinoma & 91 & 6 & 2 & \\
\hline Others & 40 & 0 & 0 & 0.214 \\
\hline \multicolumn{5}{|l|}{ TNM Stage } \\
\hline $\mathrm{I}+\mathrm{II}$ & 95 & 8 & 1 & \\
\hline $\mathrm{III}+\mathrm{IV}$ & 104 & 6 & 3 & 0.516 \\
\hline
\end{tabular}

$\mathrm{wt} / \mathrm{wt}$ represents a wild-type homozygote; $\mathrm{wt} / \mathrm{mt}$ represents a heterozygote; $\mathrm{mt} / \mathrm{mt}$ represents a homozygous mutation. $p$ value for Chi-square analysis or Fisher's exact test.

lines with the demethylating agent 5-Aza. hOGG1 mRNA expression increased in NSCLC cell lines after treatment with 5-Aza, suggesting that hOGG1 mRNA expression is associated with DNA methylation. Furthermore, using MSP, we found that the frequency of $h O G G 1$ methylation was higher in PBMCs from NSCLC patients than in those 
from controls. Although DNA methylation is frequent in NSCLC PBMCs [35], we cannot exclude the possibility that the detected methylation was derived from circulating tumor cells in the peripheral blood. Our data indicated that positive carriers of $h O G G 1$ methylation had a 2.25 -fold greater risk of developing NSCLC than methylation-free subjects in the Chinese population. Thus, our combined analysis using genetics and epigenetics revealed that the methylation status of $h O G G 1$ in PBMCs could be a marker for NSCLC.

In conclusion, we provide strong evidence of an association between the methylation of $h O G G 1$ and the risk of NSCLC. This supports the notion that peripheral lymphocytes could be used as surrogates for bronchial epithelial cells in screenings for altered DNA methylation in the development and progression of lung cancer [29, 38]. Considering that treatment with demethylating agents can restore gene expression and inactivate $h O G G 1$ [39], the use of such agents may be the ideal way to reduce the risk of developing NSCLC among individuals with $h O G G 1$ hypermethylation. A better understanding of the methylation status of BER genes may enhance cancer prevention and therapeutic interventions.

\section{Case}
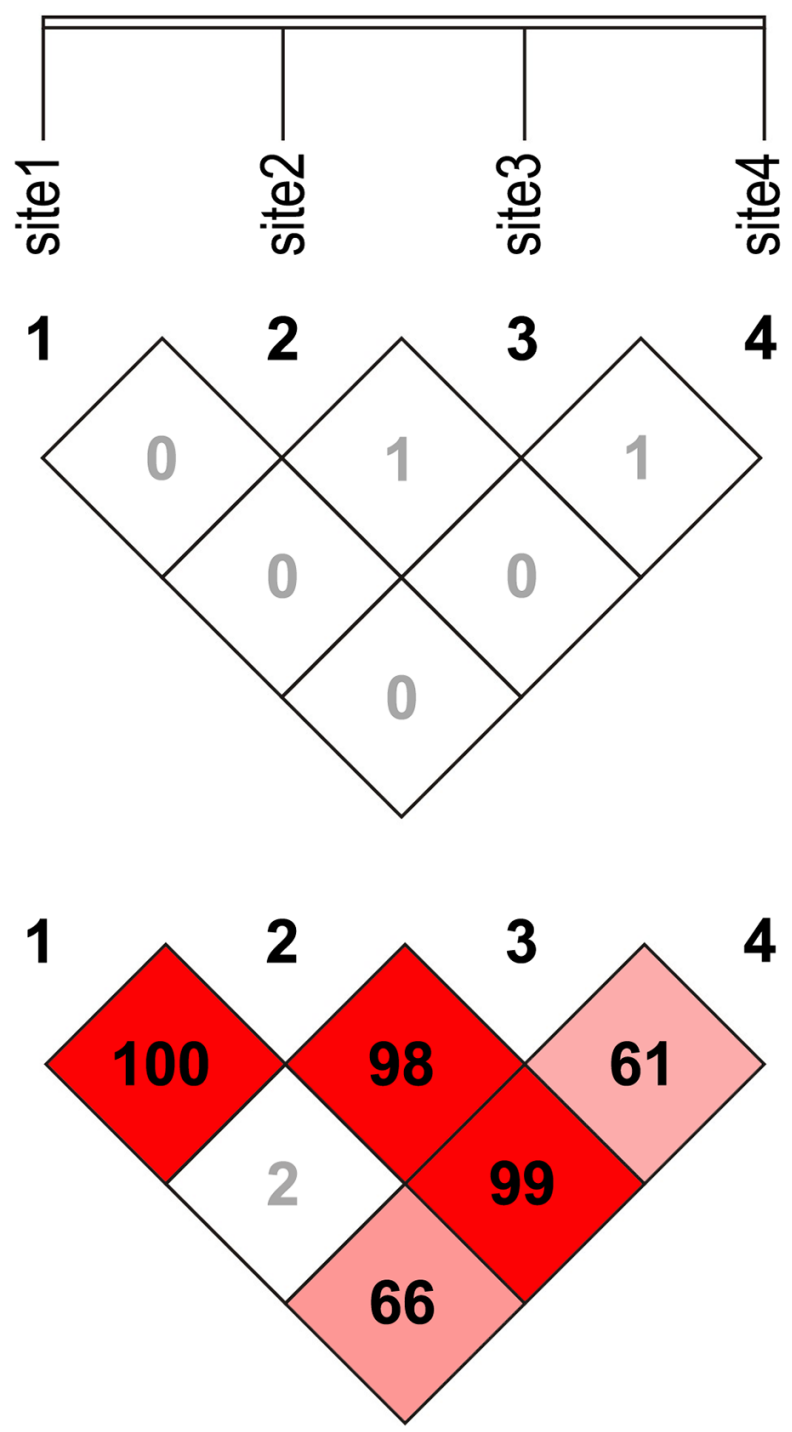

Control
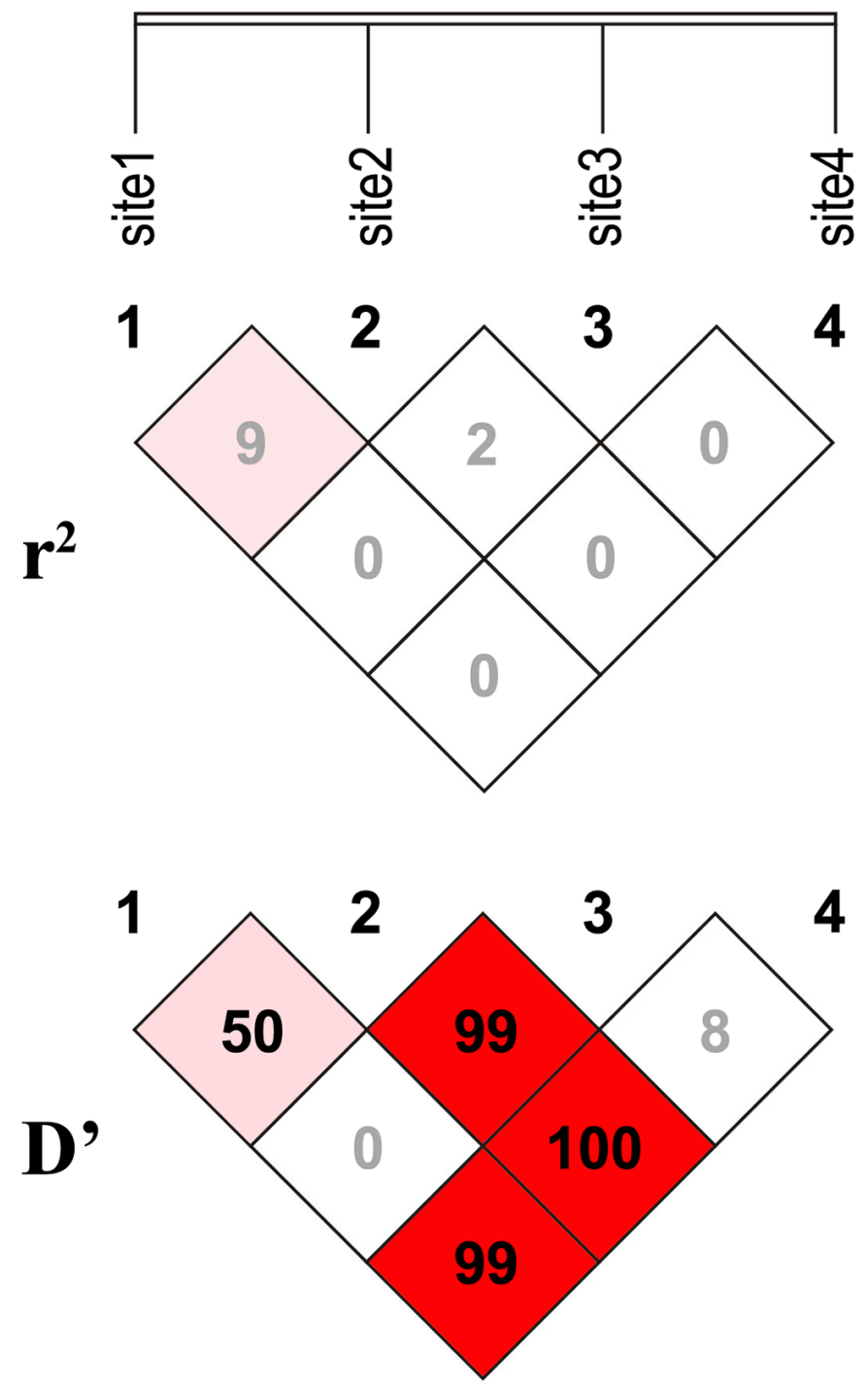

Figure 2: LD maps of the four htSNPs. LD maps of the four htSNPs of $h O G G 1$ for NSCLC cases and controls were generated by the SHEsis program. For each htSNP, $\mathrm{D}^{\prime}$ and pairwise $\mathrm{r}^{2}$ values are shown in diamonds for the two groups (NSCLC patients and healthy controls). Sites 1-4 represent rs159153, rs125701, rs159153, and rs293795, respectively. 
Table 4: Four-marker haplotype frequencies in NSCLC patients and control subjects

\begin{tabular}{lccccc}
\hline Haplotype & $\begin{array}{c}\text { Allele } \\
\text { combination }\end{array}$ & Frequencies* & Chi-square & OR(95\%CI) & $p$ \\
\hline Hap1 & TGGT & $50.4 / 50.3$ & 0.042 & $0.96(0.67-1.39)$ & 0.838 \\
Hap2 & TGCT & $36.9 / 37.7$ & 0.118 & $0.94(0.64-1.36)$ & 0.731 \\
Hap3 & CGGT & $4.1 / 3.0$ & 0.362 & $1.35(0.51-3.58)$ & 0.547 \\
Hap4 & TGGC & $3.4 / 1.6$ & 1.442 & $2.08(0.62-7.02)$ & 0.230 \\
Hap5 & CGCT & $3.0 / 3.2$ & 0.040 & $0.90(0.32-2.54)$ & 0.842 \\
\hline
\end{tabular}

* Haplotype frequencies (\%) in the NSCLC and control groups.

Table 5: Two-marker haplotype frequencies in NSCLC patients and control subjects

\begin{tabular}{ccccc}
\hline Haplotype & $\begin{array}{c}\text { Allele } \\
\text { combination }\end{array}$ & Frequencies* & Chi-square & OR(95\%CI) \\
\hline Site1\&site2 & T G & $91.5 / 90.8$ & 0.149 & $0.87(0.42-1.78)$ \\
Hap1 & C G & $7.3 / 6.3$ & 0.149 & $1.15(0.56-2.36)$ \\
Hap2 & & & 0.699 \\
Site1\&site4 & T T & $88.6 / 89.3$ & 0.044 & $0.94(0.53-1.67)$ \\
Hap1 & C T & $7.2 / 7.9$ & 0.080 & $0.91(0.46-1.79)$ \\
Hap2 & T C & $4.2 / 2.9$ & 0.575 & 0.835 \\
Hap3 & C & & 0.778 \\
\hline
\end{tabular}

* Haplotype frequencies (\%) in the NSCLC and control groups. Site 1, site 2, and site 4 represent rs159153, rs125701, and rs293795, respectively.

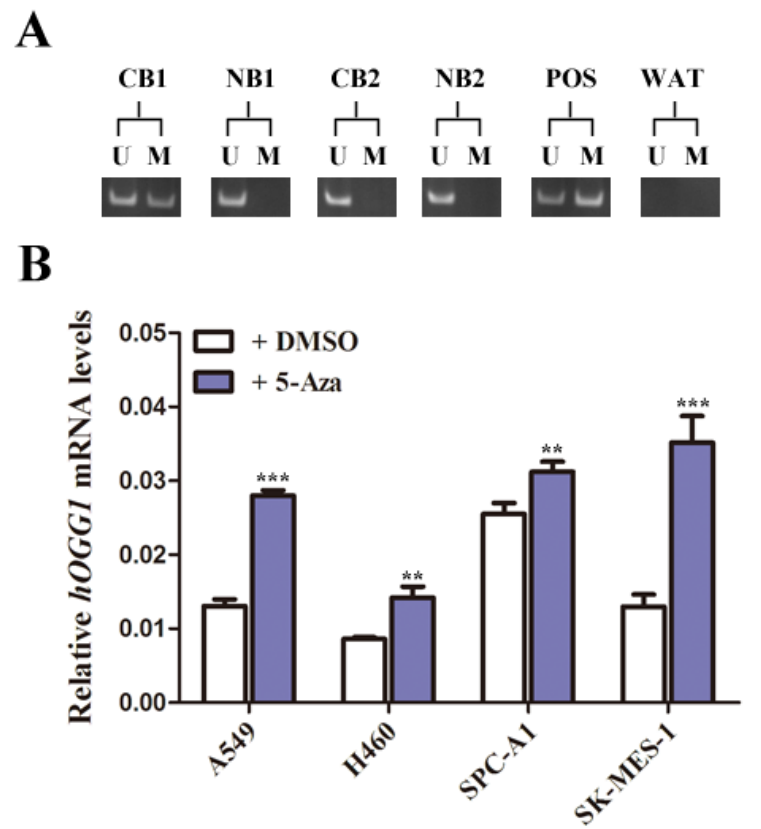

Figure 3: Methylation status analysis of $h O G G 1$ in NSCLC. A. A schematic presentation of methylation analysis of the $h O G G 1$ gene promoter, based on MSP of cancer patients' blood (CB) and normal blood (NB). POS, positive methylation; water, negative control. The presence of a PCR product in lane U indicates an unmethylated status, while M indicates a methylated status. B. NSCLC cell lines, untreated or treated with the demethylation agent 5-aza. The cells were grown to $80 \%$ confluency and were harvested on day 7 . 
Table 6: Frequency of promoter methylation for hOGG1 in NSCLC and matched non-cancerous tissue

\begin{tabular}{|c|c|c|c|c|}
\hline $\begin{array}{l}\text { hOGG1 } \\
\text { Methylation } \\
\text { Status }\end{array}$ & $\begin{array}{c}\text { Cases } \\
\mathbf{N}=\mathbf{1 2 1}, \mathbf{n}(\%)\end{array}$ & $\begin{array}{c}\text { Controls } \\
\mathrm{N}=121, \mathrm{n}(\%)\end{array}$ & $p$ & OR $(95 \% \mathrm{CI})$ \\
\hline $\mathrm{U}$ & $97(80.17)$ & $109(90.08)$ & & 1.00 \\
\hline M & $24(19.83)$ & $12(9.92)$ & 0.030 & $2.247(1.067-4.734)$ \\
\hline
\end{tabular}

$p$ value for Chi-square analysis

\section{MATERIALS AND METHODS}

\section{Patients and blood samples}

In total, 217 blood specimens were aquired after informed consent was received from patients who had been diagnosed with primary NSCLC in the First Affiliated Hospital of Soochow University between January 2003 and March 2013. The pathological stages of NSCLC patients were determined according to the Revised International System for Staging Lung Cancer. None of the NSCLC patients had received either radiotherapy or chemotherapy before blood sampling. In addition, 226 control samples were collected from individuals with no history of cancer; these participants were randomly selected from the same geographic region, and their age range was similar to that of the cancer patients. PBMCs were isolated by centrifugation at 3,500 rpm for $20 \mathrm{~min}$ after blood sampling [29]. Genomic DNA was isolated from NSCLC cell lines and blood samples through a standard proteinase $\mathrm{K}$ digestion and phenol-chloroform extraction. This study was approved by the Ethics Committee of the First Affiliated Hospital of Soochow University. A standardized questionnaire was used to collect data on age, sex, and smoking history.

\section{Cell culture and drug treatment}

Human lung carcinoma cell lines (A549, SPC-A-1, NCI-H460, and SK-MES-1) were purchased from the Cell Bank of the Chinese Academy of Sciences (Shanghai, China). A549, SPC-A-1, and NCI-H460 cells were seeded and grown in RPMI 1640 medium (HyClone, South Logan, UT, USA) with $10 \%$ heat-inactivated fetal bovine serum (Gibco, Carlsbad, CA, USA). SK-MES-1 cells were cultured in MEM (Gibco) with 10\% fetal bovine serum (Gibco), L-glutamine, and antibiotics (Invitrogen, Carlsbad, CA, USA). All cells were cultured in a humidified incubator containing $5 \% \mathrm{CO}_{2}$ at a temperature of $37^{\circ} \mathrm{C}$. 5-aza-2'deoxycytidine (Sigma-Aldrich, St. Louis, MO, USA) was used as a demethylating agent to treat the cells. The drug treatment protocol was described previously by us [29].

\section{Tagging SNP selection}

HapMap SNP Phase II data were used to determine the frequency of SNPs among Han Chinese (CHB), and five SNPs were obtained from a $15-\mathrm{kb}$ region of $h O G G 1$. One haplotype block was reconstructed from these five SNPs in the Haploview program [36]. The htSNP selection was also made in the Haploview program, through the implementation of a method proposed in our previous study [30]. A SNP was considered for inclusion in the set of htSNPs if the $\mathrm{r}^{2}$ value for its LD with at least one of the other SNPs was greater than a prespecified threshold. In our selection, only SNPs with minor allele frequencies greater than $10 \%$ were considered, and the threshold of pairwise LD was set as $r^{2}=0.8$. A total of four htSNPs within one block were selected among five SNPs considered across $h O G G 1$. The LD map of these four htSNPs is shown in Figure 4, and further information is provided in Supplementary Table 1.

\section{Genotyping}

Genomic DNA from blood specimens was isolated by standard proteinase $\mathrm{K}$ digestion and phenolchloroform extraction. The four hOGGl htSNPs were amplified by PCR. The sequences and annealing temperatures of the PCR primers are reported in Supplementary Table 2. The PCR reactions were carried out in a total volume of $25 \mu \mathrm{L}$, containing 50 to $100 \mathrm{ng}$ of genomic DNA, one unit of ExTaq DNA polymerase (Takara, Japan), $0.2 \mu \mathrm{mol} / \mathrm{L}$ of each primer, $1 \times$ Ex Taq Buffer $\left(\mathrm{Mg}^{2+}\right.$ Plus), and $0.25 \mathrm{mmol} / \mathrm{L}$ of each deoxynucleotide triphosphate.

The htSNPs were genotyped by restriction fragment length polymorphism analysis with restriction endonucleases (Supplementary Table 2). The different alleles were identified on a $2.5 \%$ agarose gel and visualized with ethidium bromide. One htSNP (rs293795) was genotyped by single-strand conformation polymorphism analysis due to the lack of a restriction endonuclease. For this procedure, the PCR products were mixed at a 1:1 ratio with loading buffer ( $95 \%$ formamide, $0.05 \%$ xylene cyanol, and $0.05 \%$ bromophenol blue), denatured at $95^{\circ} \mathrm{C}$ for $5 \mathrm{~min}$ and cooled on ice for $2 \mathrm{~min}$. Electrophoresis was performed in $8 \%$ nondenaturing polyacrylamide gels at a constant $20 \mathrm{~W}$ for $5 \mathrm{~h}$ in $1 \times$ Trisborate-EDTA running buffer, with the gel temperature maintained at $7^{\circ} \mathrm{C}$. Ethidium bromide staining was used for the detection of single-stranded DNA in the polyacrylamide gels. 


\section{LD and haplotype analysis}

Pairwise measures of LD (the Lewontin coefficient $\left[\mathrm{D}^{\prime}\right]$ and the squared correlation coefficient $\left[\mathrm{r}^{2}\right]$ ) between the genotyped SNPs were calculated with the Haploview program. The frequencies of individual haplotypes were estimated from the genotype data through the SAS 9.1.3 PROC HAPLOTYPE and SHEsis software programs [37], which reconstruct haplotypes through an expectationmaximization algorithm and a Full-Precise-Iteration algorithm, respectively. Haplotypes with a frequency of less than 0.05 were not considered in the analysis. Logistic regression analysis was performed with SAS PROC LOGISTIC to estimate the ORs and $95 \%$ confidence intervals (95\% CIs) of individual SNPs or haplotypes, with adjustment for age, sex, and smoking status.

\section{Bisulfite modification}

For methylation analysis, we collected 121 blood samples from NSCLC patients and 121 blood samples from control subjects. Genomic DNA was treated with sodium bisulfite before methylation analysis, according to the protocol of the CpGenome ${ }^{\mathrm{TM}}$ Fast DNA Modification Kit (Chemicon International, Inc.). The procedure for bisulfite modification was described in our previously published report [13]. Briefly, $1.0 \mu \mathrm{g}$ of DNA in $100 \mu \mathrm{L}$ of water was denatured for $10 \mathrm{~min}$ at $37^{\circ} \mathrm{C}$ with the addition of $7 \mu \mathrm{L}$ of freshly prepared $3 \mathrm{M} \mathrm{NaOH}$. Then, $550 \mu \mathrm{L}$ of freshly prepared DNA Modification Reagent ( $\mathrm{pH}$ 5.0) was added and well-mixed, and the mixture was incubated at $55^{\circ} \mathrm{C}$ for $20 \mathrm{~h}$. After adding $750 \mu \mathrm{L}$ of Binding Buffer, we purified the modified DNA with spin columns. Desulphonation was completed on the column by the addition of $50 \mu \mathrm{L}$ of freshly prepared $20 \mathrm{mM} \mathrm{NaOH} / 90 \%$ EtOH. Finally, DNA was eluted with $30-45 \mu \mathrm{L}$ of Elution Buffer and stored at $-20^{\circ} \mathrm{C}$ until the analysis.

\section{Methylation-specific PCR}

DNA methylation was determined by MSP, as described elsewhere. MSP can differentiate methylated alleles from unmethylated alleles of a gene-of-interest, after samples have been treated with sodium bisulfite. The primer sequences for MSP analysis of $h O G G 1$ were reported in a previous study [13]. Briefly, the PCR cycling conditions consisted of an initial denaturation at $95^{\circ} \mathrm{C}$ for $5 \mathrm{~min}$, followed by 35 cycles of $94^{\circ} \mathrm{C}$ for $30 \mathrm{sec}$, various annealing temperatures for $45 \mathrm{sec}$, and $72^{\circ} \mathrm{C}$ for $1 \mathrm{~min}$ and $15 \mathrm{sec}$. The expected PCR products were revealed by electrophoresis and visualized with ethidium bromide staining. SPC-A-1 and A549 NSCLC cell lines were used as positive controls for $h O G G 1$, while distilled water and unbisulfited DNA served as negative controls.

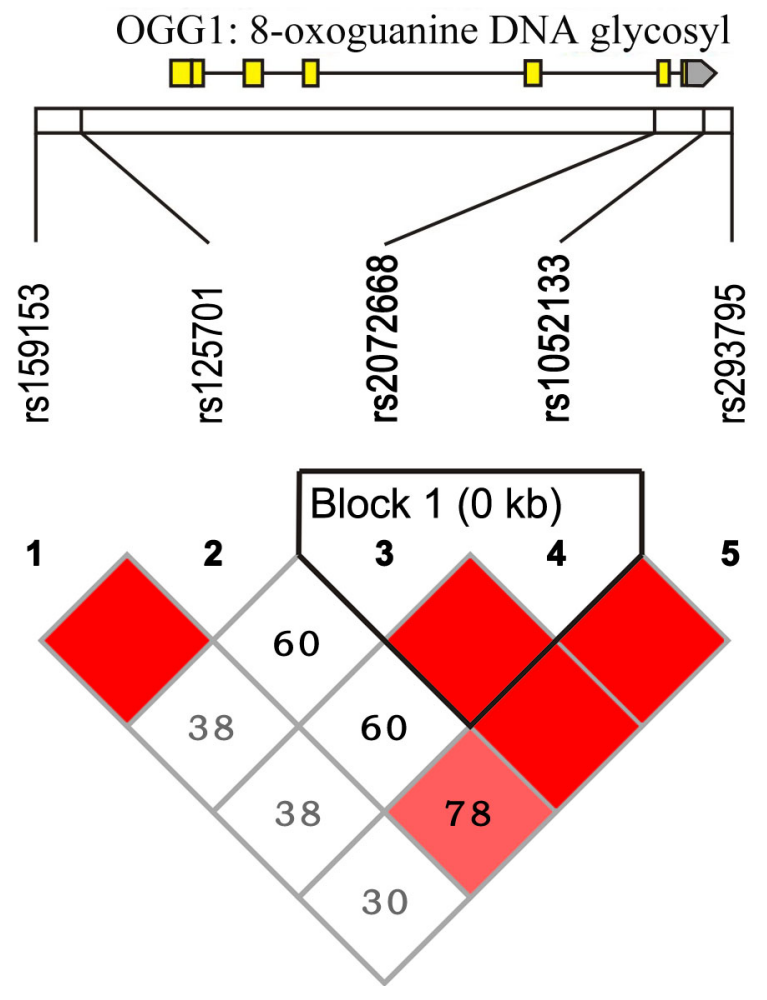

Figure 4: Pairwise LD between four htSNPs of the hOGG1 gene. The value in each diamond indicates the pairwise correlation between the tagging SNPs (measured as $r^{2}$ ) located at the upper left and right sides of the diamond. The shading with a red-to-white gradient reflects higher to lower LD values (measured as $D^{\prime}$ ). 


\section{Statistical analysis}

We used a two-sided $\chi^{2}$ test or an independentsamples $t$-test to compare the differences in gender, age, and smoking status between the NSCLC cases and controls. Hardy-Weinberg equilibrium analysis for genotype distribution in controls was carried out by a $\chi^{2}$ goodnessof-fit test. Differences in genotype and allele frequencies between cases and controls were determined with a $\chi^{2}$ test. Logistic regression was performed to assess the ORs and $95 \%$ CIs, which were adjusted for gender, age, and smoking status. All statistical analyses were performed with SAS 9.1.3., and the statistical significance cutoff was $P<0.05$.

\section{ACKNOWLEDGMENTS}

We thank all patients who participated in this study for their cooperation. This work was supported by grants from the National Natural Science Foundation of China (81201575 to Z-Y. Liu; 31270940 to J-A. Huang), the Jiangsu Province Colleges and Universities Natural Science Research Foundation (12KJB310016 to Z-Y. Liu; 14KJB0017 to Z. Lei), The science and technology projects of Suzhou (SYS201612), the Clinical Medical Center of Suzhou (Szzx201502), and the Clinical Key Specialty Project of China.

\section{CONFLICTS OF INTEREST}

None declared.

\section{REFERENCES}

1. Jemal A, Bray F, Center MM, Ferlay J, Ward E, Forman D. Global cancer statistics. CA Cancer J Clin. 2011; 61: 69-90.

2. Chen W, Zheng R, Baade PD, Zhang S, Zeng H, Bray F, Jemal A, Yu XQ, He J. Cancer statistics in China, 2015. CA Cancer J Clin. 2016; 66: 115-132.

3. Mulshine JL, Sullivan DC. Clinical practice. Lung cancer screening. N Engl J Med. 2005; 352: 2714-2720.

4. Zhong S, Fields CR, Su N, Pan YX and Robertson KD. Pharmacologic inhibition of epigenetic modifications, coupled with gene expression profiling, reveals novel targets of aberrant DNA methylation and histone deacetylation in lung cancer. Oncogene. 2007; 26:2621-2634.

5. Takamizawa J, Konishi H, Yanagisawa K, Tomida S, Osada H, Endoh H, Harano T, Yatabe Y, Nagino M, Nimura Y, Mitsudomi T and Takahashi T. Reduced expression of the let-7 microRNAs in human lung cancers in association with shortened postoperative survival. Cancer Res. 2004; 64:3753-3756.

6. Zhu J, Zeng Y, Xu C, Qin H, Lei Z, Shen D, Liu Z and Huang JA. Expression profile analysis of microRNAs and downregulated miR-486-5p and miR-30a-5p in non-small cell lung cancer. Oncol Rep. 2015; 34:1779-1786.
7. Fortini P, Pascucci B, Parlanti E, D'Errico M, Simonelli $\mathrm{V}$ and Dogliotti E. 8-Oxoguanine DNA damage: at the crossroad of alternative repair pathways. Mutat ResFundam Mol Mech Mutag. 2003; 531:127-139.

8. Evans MD, Dizdaroglu M and Cooke MS. Oxidative DNA damage and disease: induction, repair and significance. Mutat Res - Rev Mut Res. 2004; 567:1-61.

9. Fortini P and Dogliotti E. Base damage and single-strand break repair: Mechanisms and functional significance of short- and long-patch repair subpathways. DNA Repair. 2007; 6:398-409.

10. Klungland A, Rosewell I, Hollenbach S, Larsen E, Daly G, Epe B, Seeberg E, Lindahl T, Barnes DE. Accumulation of premutagenic DNA lesions in mice defective in removal of oxidative base damage. Proc Natl Acad Sci U S A. 1999; 96: 13300-13305.

11. Radicella JP, Dherin C, Desmaze C, Fox MS, Boiteux S. Cloning and characterization of hOGG1, a human homolog of the OGG1 gene of Saccharomyces cerevisiae. Proc Natl Acad Sci U S A. 1997; 94: 8010-8015.

12. Rosenquist TA, Zharkov DO, Grollman AP. Cloning and characterization of a mammalian 8-oxoguanine DNA glycosylase. Proc Natl Acad Sci U S A. 1997; 94 : 7429-7434.

13. Liu Z, Zhao J, Chen XF, Li W, Liu R, Lei Z, Liu X, Peng X, $\mathrm{Xu} \mathrm{K}$, Chen J, Liu H, Zhou QH and Zhang HT. CpG island methylator phenotype involving tumor suppressor genes located on chromosome $3 p$ in non-small cell lung cancer. Lung Cancer. 2008; 62:15-22.

14. Sampath H, Vartanian V, Rollins MR, Sakumi K, Nakabeppu Y and Lloyd RS. 8-Oxoguanine DNA glycosylase (OGG1) deficiency increases susceptibility to obesity and metabolic dysfunction. PloS one. 2012; 7:e51697.

15. Sheng Z, Oka S, Tsuchimoto D, Abolhassani N, Nomaru H, Sakumi K, Yamada H, Nakabeppu Y. 8-Oxoguanine causes neurodegeneration during MUTYH-mediated DNA base excision repair. J Clin Invest. 2012; 122: 4344-4361.

16. Peng Y, Li Z, Zhang S, Xiong Y, Cun Y, Qian C, Li M, Ren T, Xia L, Cheng Y and Wang D. Association of DNA base excision repair genes (OGG1, APE1 and $\mathrm{XRCC} 1$ ) polymorphisms with outcome to platinum-based chemotherapy in advanced nonsmall-cell lung cancer patients. Int J Cancer. 2014; 135:2687-2696.

17. Kohno T, Kunitoh H, Toyama K, Yamamoto S, Kuchiba A, Saito D, Yanagitani N, Ishihara S, Saito R and Yokota J. Association of the OGG1-Ser326Cys polymorphism with lung adenocarcinoma risk. Cancer Sci. 2006; 97:724-728.

18. Le Marchand L, Donlon T, Lum-Jones A, Seifried A, Wilkens LR. Association of the hOGG1 Ser326Cys polymorphism with lung cancer risk. Cancer Epidemiol Biomarkers Prev. 2002; 11: 409-412.

19. Sugimura H, Kohno T, Wakai K, Nagura K, Genka K, Igarashi H, Morris BJ, Baba S, Ohno Y, Gao C, Li Z, Wang 
J, Takezaki T, et al. hOGG1 Ser326Cys polymorphism and lung cancer susceptibility. Cancer Epidemiol Biomarkers Prev. 1999; 8: 669-674.

20. Zhong DY, Chu HY, Wang ML, Ma L, Shi DN, Zhang ZD. Meta-analysis demonstrates lack of association of the hOGG1 Ser326Cys polymorphism with bladder cancer risk. Genet Mol Res. 2012; 11: 3490-3496.

21. Tu ZB, Feng AL, Li L and Zhou SF. No Association between hOGG1 Ser326Cys Polymorphism and Hepatocellular Carcinoma. Hepato-Gastroenterol. 2013; 60:1101-1104.

22. Hu WG, Pan RJ, Cai W, Wang ZT and Zhu ZG. Lack of association between the hOGG1 gene Ser326Cys polymorphism and gastric cancer risk: evidence from a case-control study and a meta-analysis. Gen Mol Res. 2015; 14:14670-14679.

23. Geng PL, Yao J and Zhu YF. hOGG1 Ser326Cys polymorphism and lung cancer susceptibility: a metaanalysis. Mol Biol Rep. 2014; 41:2299-2306.

24. Irizarry RA, Ladd-Acosta C, Wen B, Wu ZJ, Montano C, Onyango P, Cui HM, Gabo K, Rongione M, Webster M, Ji H, Potash JB, Sabunciyan S and Feinberg AP. The human colon cancer methylome shows similar hypo- and hypermethylation at conserved tissue-specific $\mathrm{CpG}$ island shores. Nat Genet. 2009; 41:178-186.

25. Herman JG and Baylin SB. Mechanisms of disease: Gene silencing in cancer in association with promoter hypermethylation. New Engl J Med. 2003; 349:2042-2054.

26. Das PM, Singal R. DNA methylation and cancer. J Clin Oncol. 2004; 22: 4632-4642.

27. Sekido Y, Fong KM, Minna JD. Progress in understanding the molecular pathogenesis of human lung cancer. Biochim Biophys Acta. 1998; 1378: F21-59.

28. Doi A, Park IH, Wen B, Murakami P, Aryee MJ, Irizarry R, Herb B, Ladd-Acosta C, Rho J, Loewer S, Miller J, Schlaeger T, Daley GQ and Feinberg AP. Differential methylation of tissue- and cancer-specific $\mathrm{CpG}$ island shores distinguishes human induced pluripotent stem cells, embryonic stem cells and fibroblasts. Nat Genet. 2009; 41:1350-1353.

29. Liu Z, Li W, Lei Z, Zhao J, Chen XF, Liu R, Peng X, Wu ZH, Chen J, Liu H, Zhou QH, Zhang HT. CpG island methylator phenotype involving chromosome $3 p$ confers an increased risk of non-small cell lung cancer. J Thorac Oncol. 2010; 5: 790-797.
30. Lei Z, Liu RY, Zhao J, Liu Z, Jiang X, You W, Chen XF, Liu X, Zhang K, Pasche B and Zhang HT. TGFBR1 haplotypes and risk of non-small-cell lung cancer. Cancer Res. 2009; 69:7046-7052.

31. Kim Y and Kim DH. CpG island hypermethylation as a biomarker for the early detection of lung cancer. Methods Mol Biol. 2015; 1238:141-171.

32. Konecny M, Markus J, Waczulikova I, Dolesova L, Kozlova $\mathrm{R}$, Repiska V, Novosadova $\mathrm{H}$ and Majer I. The value of SHOX2 methylation test in peripheral blood samples used for the differential diagnosis of lung cancer and other lung disorders. Neoplasma. 2016; 63:246-253.

33. De Ruyck K, Szaumkessel M, De Rudder I, Dehoorne A, Vral A, Claes K, Velghe AA, Van Meerbeeck J and Thierens H. Polymorphisms in base-excision repair and nucleotideexcision repair genes in relation to lung cancer risk. Mutat Res-Genet Toxicol Environ Mutag. 2007; 631:101-110.

34. Smart DJ, Chipman JK and Hodges NJ. Activity of OGG1 variants in the repair of pro-oxidant-induced 8-oxo-2 '-deoxyguanosine. DNA Repair. 2006; 5:1337-1345.

35. Baylin SB and Ohm JE. Epigenetic gene silencing in cancer - a mechanism for early oncogenic pathway addiction? Nat Rev Cancer. 2006; 6:107-116.

36. Barrett JC, Fry B, Maller J and Daly MJ. Haploview: analysis and visualization of LD and haplotype maps. Bioinformatics. 2005; 21:263-265.

37. Shi YY and He L. SHEsis, a powerful software platform for analyses of linkage disequilibrium, haplotype construction, and genetic association at polymorphism loci. Cell Res. 2005; 15:97-98.

38. Russo AL, Thiagalingam A, Pan HJ, Califano J, Cheng KH, Ponte JF, Chinnappan D, Nemani P, Sidransky D and Thiagalingam S. Differential DNA hypermethylation of critical genes mediates the stage-specific tobacco smokeinduced neoplastic progression of lung cancer. Clin Cancer Res. 2005; 11:2466-2470.

39. Suzuki M, Sunaga N, Shames DS, Toyooka S, Gazdar AF and Minna JD. RNA interference-mediated knockdown of DNA methyltransferase 1 leads to promoter demethylation and gene re-expression in human lung and breast cancer cells. Cancer Res. 2004; 64:3137-3143. 